\title{
Pharmaciana
}

Vol.11, No.3, Nov 2021, Page. 303-311

ISSN: 2088 4559; e-ISSN: 24770256

DOI: $10.12928 /$ pharmaciana.v11i3.17617

\section{Topical anti-inflammatory effect of Ekor Naga (Rhaphidophora pinnata (L.f) Schott) leaves extract}

\author{
Bernike Anastasia Tarigan, Fathnur Sani K*, Muhaimin \\ Pharmacy Study Program, Faculty of Medicine and Public Health Sciences, Jambi University \\ Jl. Jambi-Ma. Bulian KM 15 Mendalo Darat Jambi 36361, Indonesia
}

Submitted: 11-08-2020

Reviewed: 12-06-2021

Accepted: 29-09-2021

\begin{abstract}
Ekor Naga (Rhaphidophora pinnata (L.f) Schott) leaves are leaves that contain secondary metabolites which can be developed into medicine. Ekor Naga leaves have secondary metabolite compounds of flavonoids, alkaloids, triterpenoid saponins, steroids, tannins, and phenols. This metabolite compound is the basis for testing the anti-inflammatory effect of Ekor Naga leaves extract using topical methods. The purpose of this study was to determine the anti-inflammatory effect of the ethanol extract of Ekor Naga leaves by a topical method. This study used five treatment groups with five mice in each treatment. This research tested the anti-inflammatory activity of Ekor Naga leaves extract by using the combination of 2 methods; namely the method of forming airbags and the formation of artificial edema using the induction of $2 \%$ carrageenan solution with the observation parameters being the measurement of exudate volume and differentiation of the number of leukocyte cells observed under a microscope. The results showed that the Ekor Naga leaves extract had an antiinflammatory effect. The best inflammatory effect is a concentration of $10 \%$, followed by a concentration of $5 \%$ and $2.5 \%$.
\end{abstract}

Keyword: Ekor Naga leaves extract, anti-inflammatory, leucocyte cells, topical

\section{*Corresponding author:}

Fathnur Sani K

Pharmacy Study Program, Faculty of Medicine and Public Health Sciences Jambi University

Jl. Jambi-Ma. Bulian KM 15 Mendalo Darat Jambi 36361, Indonesia

Email: fathnursanik@unja.ac.id 


\section{INTRODUCTION}

Inflammation is an initial response to the body caused by stimulation from chemical, physical, or foreign microorganism infections that can cause tissue damage. The stimulation of inflammatory mediators such as histamine, serotonin, bradykinin, prostaglandin released in the body can cause vasodilation and an increase in blood vessel permeability (Kumar et al., 2018; Stankov, 2012). The commonly used anti-inflammatory therapies are anti-inflammatory steroids and non-steroidal antiinflammatory that works by suppressing and reducing inflammation. Anti-inflammatory drugs used in the long term have some side effects that can reduce the function of organs like kidneys, liver, digestive system, and heart. To reduce the side effects of using anti-inflammatory drugs, it is necessary to seek traditional medicine as an alternative to inflammatory therapy that can reduce pain and inflammation with fewer side effects and toxicity (Sukmawati et al., 2015).

Traditional medicine is the non-conventional treatment aimed at improving community health status, including promotive, preventive, curative, and rehabilitative. Ekor Naga leaves (Rhaphidophora pinnata (L.f) Schott) is one of the traditional plants that is often used by the public as a cure for cancer, tumors, rheumatism, coughs, and clean dirty blood. Other than that, Ekor Naga leaves contain flavonoids, saponins, tannins, alkaloids, glycosides, and steroids/triterpenoids (Sumaiyah et al., 2018). Ekor Naga leaves also have several supporting research results that can support the anti-inflammatory test. This research was supported by the result of research done by Rahman and Andi (2019), which states that Ekor Naga leave has an effect as a wound healing. It is where one of the phases in wound healing is the inflammatory phase. In the late inflammatory phase of wound repair, T-Lymphocytes appear in the wound bed and may influence the resolution and remodeling of the wound. As inflammation resolves and the number of leucocytes diminishes, the wound undergoes a lengthy period of remodeling and resolution. Although inflammation is not prominent during this resolution phase, many studies suggest that the event of the inflammatory phase has profound effects on the final wound outcome (Koh and DiPietro, 2011). This is because Ekor Naga leaves contain flavonoids that function like apigenin-8-C-B-D-glucopyranoside (Vitexin) and several types of phenolic that inhibit cell proliferation and affect cell proliferation repair, and reducing many leukocytes. Meanwhile, the steroid compounds in Ekor Naga leaves can inhibit the phospholipase A2 enzyme in synthesizing arachidonic acid in the formation of inflammatory mediators. Saponin compounds in Ekor Naga leaves can increase the interleukin factor (Borgi et al., 2008; Deli, 2007).

Topical treatment provides local treatment by applying it to the skin surface, where the drug must be able to penetrate through the barrier to its place of action. The drug will have an effect depending on the level of the drug that reaches its workplace. The advantages of topical drug administration are that the drug can work locally, avoid the first-pass metabolism, use on irritated and inflamed skin (Cho and Bashaw, 2011).

Based on the data above, the researchers felt the need to make research on the anti-inflammatory activity test of Ekor Naga leaves extract (Rhaphidophora pinnata (Lf) Schott) in male white mice smeared on the skin of the mice's back, using a combination method of forming air sacs and artificial edema in rat's back which induces a subcutaneous carrageenan solution. The results obtained can provide additional information about the benefits of using Ekor Naga leaves extract as a natural medicine with anti-inflammatory properties.

\section{MATERIALS AND METHOD}

\section{Materials}

Fresh Ekor Naga leaves (Rhaphidophora pinnata (L.f) Shcott) was taken from Sungai Penuh Kerinci City, Jambi Province in January 2020 Hydrocortisone (PT. Kimia Farma Tbk), carrageenan (CV. Genera Labora), and Vaseline flavum (PT. Brataco), 70\% ethanol (PT. Brataco); aquadest; Mayer, Wagner, and Dragendorf reagents. 


\section{Method}

\section{Simplicia preparation}

The Ekor Naga leaves were collected then sorted. The leaves of the petioles were separated then washed with running water three times to remove impurities that were still attached to the leaves. Furthermore the Ekor Naga leaves were chopped into small pieces to 1-2 $\mathrm{cm}$ in size to speed up the drying process. The wind method played an important role in drying the Ekor naga leaves. The researcher then weighed the dry sample until it reached the constant weight and ground it to be pollinated.

\section{Preparation of Ekor Naga leaves extract}

Extraction of the Ekor Naga leaves was done using the $70 \%$ ethanol solvent maceration method. The container was the place to put simplicia powder; next, a 70\% ethanol solvent was added until the powder was submerged. Next, it was covered and left for five days, must be protected from the light; it had to be stirred every day. The mixture was filtered by a funnel covered with filter paper. The dregs were macerated by an ethanol $70 \%$, and it was left for two days. The next step was filtering again until the solvent obtained maceration. The macerate was concentrated by a rotary evaporator at a temperature which not exceed $400 \mathrm{C}$ until the thick extract was produced.

\section{Anti-inflammatory activity test}

The research was conducted using male white mice Swiss Webster with a bodyweight of $20-30$ grams. All mice were purchased from Galih Farm; the address was in Kota Jambi, Jambi Province. Previously all mice had also been examined by drh. Rospita Pane (from the agriculture and food defense department with a certificate number 524.3/35/DPKP/SKKH/2020). This research had also passed an ethical review with a certificate number 352/UN.16.2/Kep-FK/2020 by the ethics committee team of Andalas University Faculty of Medicine. This research had conducted using five treatments, namely :

Negative Control = Mice were given hydrocortisone acetate $2.5 \%$

$\mathrm{C} 1=$ Mice were given extract of Ekor Naga leave $2.5 \%$

$\mathrm{C} 2=$ Mice were given extract of Ekor Naga leave $5 \%$

C3 $=$ Mice were given extract of Ekor Naga leave $10 \%$

The induction of inflammation on mice refers to the study of Aria et al. (2015), where the back of the mice was shaved with a diameter of three $\mathrm{cm}$ and followed by the application of hair removal cream to completely remove the remaining hair and left for twenty-four hours before testing. On the first day of testing, the shaved back was injected with $5 \mathrm{ml}$ of air subcutaneously on the back to form an air sac. On the third day, $3 \mathrm{ml}$ of air was re-injected subcutaneously. Then on the fourth day after air injection, $0.5 \mathrm{ml}$ of $2 \%$ carrageenan solution was injected into the airbag to produce an inflammatory response.

The anti-inflammatory test refers to Anilkumar et al. (2017). On the fourth day of testing, after being injected with a $2 \%$ carrageenan solution in the treated mice, $0.1 \mathrm{gr}$ of Ekor Naga leaves extract was applied evenly, vaseline flavum in the negative control group, and hydrocortisone acetate $2.5 \%$ in the control group positive. The extract was applied on the 4th, 5th, 6th, and 7th days after injection of the $1 \%$ carrageenan solution.

\section{Exudate volume measurement}

Exudate volume measurement refers to the research done by Dillasamola et al. (2016). On day eight, the mice were sacrificed by cervical dislocation. Furthermore, the air sac tissue on the skin of the mice's back was dissected and split open to suck up the exudate volume using a syringe and measured using a measuring cup. The inflammation inhibition calculation refers to the average inflammation inhibition calculated by the formula: 
$\%$ Inflammation inhition $=\frac{a-b}{a} \times 100 \%$

$\mathrm{a}=$ Negative control group average inflammation volume $(\mathrm{ml})$

$\mathrm{b}=$ An average inflammation volume of the test group or control drug treatment group (mL)

\section{Leucocyte counting}

On the eighth day, the blood of the mice's tail was taken, dripped into an object-glass, and made smear preparations. After drying, the smears were fixed using methanol for 3-5 minutes. Next, after drying, color with Giemsa dye for 10 minutes and rinse with aquadest. Then the preparations were given immersion oil. Leucocyte was examined using a microscope with a magnification of 100 times counting each leukocyte. The cells were counted at least 100 cells and calculated the percentage of leukocyte types. If the calculation had reached 100 cells before reaching zone IV, then the calculation was continued so that the number of cells exceeded 100. The relative value of each leukocyte was expressed in percentage. The relative value was obtained by dividing the number of leukocytes in one type of leukocyte by 100, then multiplied by 100\% (Hamghalam and Ayatollahi, 2009).

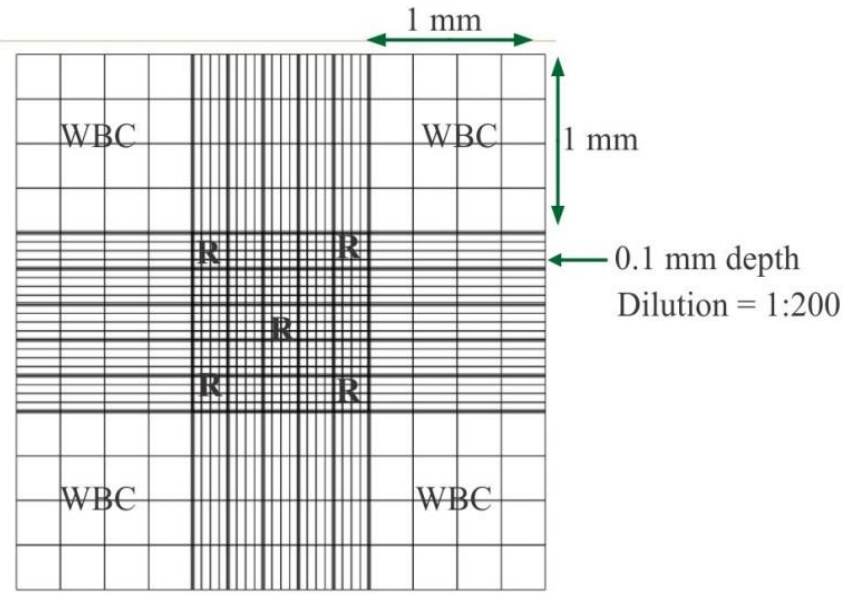

Figure 1. Leucocyte cells counting in the chamber

\section{Data Analysis}

The data obtained were analyzed using a one-way ANOVA with a 95\% confidence level followed by the Duncan test.

\section{RESULT AND DISCUSSION}

The simplicia of Ekor Naga leaves was carried out wet sorting and then dried to air in the open air at room temperature. The purpose of drying fresh leaves is to reduce the water content to prevent rot and the growth of microorganisms while stopping enzymatic reactions and chemical changes. The parameter that shows the leaves have dried completely is that the leaves can be mashed. The result of Ekor Naga leaves simplicia obtained was $25.6 \%$. The purpose of determining the simplicia yield, according to Nuralifah et al. (2018), is to determine the approximate amount of simplicia needed in making thick extracts. Meanwhile, the thick yield of Ekor Naga leaves extract was $12.71 \%$.

The specific parameter tested on the Ekor Naga leaves was the organoleptic test. According to Syukri et al. (2020), determining the specific parameters of the extract aims to conduct a subjective initial introduction to the extract using the senses. The results obtained from the Ekor Naga leaves extract is a thick greenish brown extract, has a chaste taste and distinctive smell. The results of the phytochemical screening test, the data obtained can be seen in Table 1 . 
Table 1. Phytochemical screening test results

\begin{tabular}{llc}
\hline Number & \multicolumn{1}{c}{ Testing } & Information \\
\hline $\mathbf{1 .}$ & Alkaloid Test & + \\
& a. Mayer & + \\
& b. Dragendorff & + \\
$\mathbf{2 .}$ & Flavonoid Test & + \\
$\mathbf{3 .}$ & Saponin Test & + \\
$\mathbf{4 .}$ & Tannin Test & + \\
$\mathbf{5 .}$ & Steroid/Triterpenoid Test & + \\
$\mathbf{6 .}$ & Fenol Test & \\
\hline
\end{tabular}

Notes Information : (+) : contains a group of compounds

The results of the qualitative phytochemical screening test showed that Ekor Naga leaves extract contained alkaloids, flavonoids, saponins, tannins, steroids/triterpenoids, and the phenol test showed positive results. This result is in line with the results of research by Masfria et al. (2014). The experimental results of the average exudate volume obtained can be seen in Table 2 .

Table 2. Mean exudate volume \pm SD and percentage of inhition

\begin{tabular}{ccc}
\hline Treatment Group & $\begin{array}{c}\text { Exudate Volume } \\
(\mathbf{m l})\end{array}$ & $\begin{array}{c}\text { Percentage of Inhibition } \\
(\boldsymbol{\%})\end{array}$ \\
\hline Positive Control & $0.006 \pm 0.01^{\mathrm{a}}$ & 93.47 \\
Negative Control & $0.092 \pm 0.02^{\mathrm{e}}$ & - \\
C1 & $0.071 \pm 0.01^{\mathrm{d}}$ & 22.82 \\
C2 & $0.047 \pm 0.02^{\mathrm{c}}$ & 48.91 \\
C3 & $0.018 \pm 0.01^{\mathrm{b}}$ & 80.43 \\
\hline
\end{tabular}

Notes

a. The significance value was determined by one-way ANOVA analysis with a 95\% confidence level.

b. Different lowercase superscripts on the same line indicated a significant difference $(\mathrm{P}<0.05)$.

Reduction of exudate fluid occurs due to the reduction of damaging membrane lipids, this mechanism occurs through the production of inflammatory mediators such as histamine and prostaglandins so that the formation of exudate fluid can be inhibited and reduced (Abdulkhaleq et al., 2018). In this study, the inducer used was carrageenan. Carrageenan is a mucopolysaccharide obtained from Irish seaweed (Chondrus crispus). Carrageenan is useful in the formation of acute edema (Singh et al., 2008). Where carrageenan functions as a foreign substance (antigen) which when it enters the body will stimulate the release of inflammatory mediators such as histamine so that inflammation occurs due to antibodies that react to these antigens to counter their effects (Necas and Bartosikova, 2013). According to Lee et al. (2015), saponin compounds can inhibit the release of pro-inflammatory substances stimulated by LPS, such as iNOS, IL, and TNF- $\alpha$, so they can inhibit the formation of fluid exudates and inhibit the permeability of the vascular system. In addition, flavonoids can inhibit the secretion of lysosomes that cause profeliration and exudation so that by reducing lysosome secretion, exudate formation can be inhibited (Abdulkhaleq et al., 2018). The result of the different types of leukocytes measurements can be found in Table 3. 
Table 3. The average \pm SD number of leukocytes in the Ekor Naga leaves activity test Average Number of Leukocyte Cells

\begin{tabular}{ccccc}
\hline & $\begin{array}{c}\text { Stem } \\
\text { Neutrophils }\end{array}$ & $\begin{array}{c}\text { Segmented } \\
\text { Neutrophils }\end{array}$ & Monocytes & Lymphocytes \\
\hline Positive Control & $4.40 \pm 0.400^{\mathrm{a}}$ & $16.40 \pm 0.245^{\mathrm{a}}$ & $1.60 \pm 0.245^{\mathrm{a}}$ & $85.60 \pm 0.400^{\mathrm{e}}$ \\
Negative & $35.40 \pm 0.245^{\mathrm{e}}$ & $39.60 \pm 0.400^{\mathrm{d}}$ & $3.60 \pm 0.245^{\mathrm{c}}$ & $25.20 \pm 0.374^{\mathrm{a}}$ \\
Control & & & & \\
C1 & $34.40 \pm 0.245^{\mathrm{d}}$ & $40.00 \pm 0.316^{\mathrm{d}}$ & $2.80 \pm 0.200^{\mathrm{b}}$ & $33.60 \pm 0.244^{\mathrm{b}}$ \\
C2 & $29.40 \pm 0.245^{\mathrm{c}}$ & $28.20 \pm 0.200^{\mathrm{c}}$ & $1.80 \pm 0.200^{\mathrm{a}}$ & $72.40 \pm 0.244^{\mathrm{c}}$ \\
C3 & $12.40 \pm 0.245^{\mathrm{b}}$ & $14.8 \pm 0.375^{\mathrm{b}}$ & $1.40 \pm 0.245^{\mathrm{a}}$ & $79.20 \pm 0.374^{\mathrm{d}}$ \\
\hline
\end{tabular}

Notes Information:

a. The significance value was determined by one-way ANOVA analysis with a $95 \%$ confidence level.

b. Different lowercase superscripts on the same line indicated a significant difference $(\mathrm{P}<0.05)$.

The data obtained showed that carrageenan-induced mice experienced acute inflammation as indicated by an increase in the number of stem neutrophils and segment neutrophils, which were an inflammatory response due to the induction of carrageenan chemical compounds Phillipson and Kubes (2019). Inflammation is a physiological response to injury characterized by complex processes which are aimed to restore tissue homeostasis. Its first stage comprises the quick activation and migration of immune cells to the injury site to prevent the invasion of microorganisms and damage by hazardous substances in the absence of tissue integrity. In this context, neutrophils play an important role, arriving at the site of inflammation in a multistep controlled process that encompasses marginalization, slow-rolling, adhesion, and transendothelial or albuminal migration (Dabrowski et al. 2014; Thome et al. 2018). All these processes are dependent on the specific interactions between proteins expressed on endothelial cells and leukocytes, such as integrins and selectins(Schmidt et al., 2013; Thome et al., 2018). The topical administration of Ekor Naga leaves extract in each group showed a significant difference compared to the negative control. It is in line with the research conducted by Pastar et al. (2014) and Behl et al. (2021). The existence of flavonoid compounds found in Ekor Naga leaves according to the research of Benvenutti et al. (2021), can reduce the number of leukocytes when inflammation occurs in inhibiting chemotaxis reactions so that the inflammatory response can be reduced. In addition, saponin compounds contained in Ekor Naga leaves can increase the production of inflammatory mediators, namely growth factors for the formation of vascular endothelium and interleukins, so that they can induce macrophages to areas experiencing inflammation. Other than neutrophils, monocyte cells also have an important role in fighting pathogens that can cause inflammation. The interactions between neutrophils and monocytes/ macrophages enable the host to efficiently defend against and eliminate foreign pathogens that can cause inflammation (Kumar et al., 2018).

Injection of carrageenan also caused a decrease in the number of lymphocytes from its normal value, namely according to Fahrimal et al. (2014) the normal value of lymphocytes in mice was 55$95 \%$. The decrease in the number of lymphocytes induced by carrageenan is caused by the body's compensatory reaction when there is inflammation. The increase in the number of lymphocytes after administration of an Ekor Naga leaves extract was due to the activity of secondary metabolites contained in the Ekor Naga leaves extract, namely flavonoids, alkaloids, saponins, and tannins. These secondary metabolites have mutually supportive effects in increasing the body's response to cell damage or inflammation. Lymphocytes are important cell populations involved in chronic inflammation. Those cells can regulate the immune system, eliminate infected cells and orchestrate immune response by producing and secreting different kinds of cytokines. Cytokines, such as IL-2, TNF- $\alpha$, and IFN- $\gamma$, are important in the progression of an inflammatory response aiming return to the homeostasis (Araújo et al. 2019) 
Based on the results of the data above, it can be seen that the secondary metabolite compounds contained in the Ekor Naga leave extract, namely flavonoids, alkaloids, triterpenoids/steroids, tannins, and saponins have anti-inflammatory activity that plays a role in reducing inflammation. According to Abdulkhaleq et al. (2018), flavonoids can inhibit the activity of the cyclooxygenation and lipoxygenase enzymes. The process of inhibiting this enzyme can inhibit the biosynthetic metabolism of the formation of prostaglandins and leukotrienes which are products of the enzymes cyclooxygenase and lipooxygenase. So that the number of leukocytes that have accumulated in the inflamed area can be reduced. In addition, flavonoids can also inhibit lysosome secretion which causes profeliration and exudation. Saponin compounds can inhibit the release of pro-inflammatory substances stimulated by LPS, such as iNOS, IL, and TNF- $\alpha$, so that they can inhibit the formation of fluid exudates and inhibit the permeability of the vascular system Lee et al., (2015). Then the steroids found in Ekor Naga leaves can also inhibit inflammation through inhibition of the phospholipase enzyme so that the formation of arachidonic acid and prostaglandins can be stopped. Steroids also play a role in inhibiting the migration of leukocyte infiltration.

\section{CONCLUSION}

The Ekor Naga leaves extract that applied topically (concentrations of 2.5\%, 5\%, and 10\%) have an anti-inflammatory activity which is characterized by a decrease in the volume of exudate fluid and the number of types of leukocyte cells. The best concentration in overcoming inflammation is a concentration of $10 \%$, with an inhibition percentage of $80.43 \%$.

\section{REFERENCES}

Abdulkhaleq, L. A., Assi, M. A., Abdullah, R., Zamri-Saad, M., Taufiq-Yap, Y. H., \& Hezmee, M. N. M. (2018). The crucial roles of inflammatory mediators in inflammation: A review. Veterinary World, 11(5), 627-635. https://doi.org/10.14202/vetworld.2018.627-635

Anilkumar, K., Reddy, G. V., Azad, R., Yarla, N. S., Dharmapuri, G., Srivastava, A., Kamal, M. A., \& Pallu, R. (2017). Evaluation of Anti-Inflammatory Properties of Isoorientin Isolated from Tubers of Pueraria tuberosa. Oxidative Medicine and Cellular Longevity. https://doi.org/10.1155/2017/5498054

Araújo, C. R. R., De Melo Silva, T., Dos Santos, M. G., Ottoni, M. H. F., De Souza Fagundes, E. M., De Sousa Fontoura, H., De Melo, G. E. B. A., \& De Carvalho Alcântara, A. F. (2019). Antiinflammatory and cytotoxic activities of the extracts, fractions, and chemical constituents isolated from Luehea ochrophylla Mart. BMC Complementary and Alternative Medicine, 19(1), 1-10. https://doi.org/10.1186/s12906-019-2701-7

Audina, M., \& Khaerati, K. (2018). Efektivitas AntiinflamasiI Ekstrak Etanol Daun Sumambu ( Hyptis capitata Jacq .) Pada Tikus Jantan ( Rattus norvegicus L .). Bocelebes.

Behl, T., Kumar, K., Brisc, C., Rus, M., Nistor-Cseppento, D. C., Bustea, C.,et al., (2021). Exploring the multifocal role of phytochemicals as immunomodulators. Biomedicine and Pharmacotherapy, 133(September 2020), 110959. https://doi.org/10.1016/j.biopha.2020.110959

Benvenutti, L., Nunes, R., Venturi, I., Ramos, S. A., Broering, M. F., Goldoni, F. C., Pavan, S. E., Verônica, M., Pastor, D., Malheiros, A., Lins, N., Quintão, M., Fernandes, E. S., \& Santin, J. R. (2021). Anti-Inflammatory and Healing Activity of the Hydroalcoholic Fruit Extract of Solanum diploconos ( Mart .) Bohs. 2021.

Borgi, W., Recio, M. C., Ríos, J. L., \& Chouchane, N. (2008). Anti-inflammatory and analgesic activities of flavonoid and saponin fractions from Zizyphus lotus (L.) Lam. South African Journal of Botany, 74(2), 320-324. https://doi.org/10.1016/j.sajb.2008.01.009

Cho, S., \& Bashaw, E. D. (2011). Clinical pharmacology for development of topical dermatological products: Present and future opportunities for safety and efficacy. In Clinical Pharmacology and Therapeutics. https://doi.org/10.1038/clpt.2010.283

Topical anti-inflammatory... (Taringan et al.,) 
Dabrowski, A., Osada, J., Dabrowska, M. I., Wereszczynska-Siemiatkowska, U., \& Siemiatkowski, A. (2014). Increased expression of the intercellular adhesion molecule-1 (ICAM-1) on peripheral blood neutrophils in acute pancreatitis. Advances in Medical Sciences, 59(1), 102-107. https://doi.org/10.1016/j.advms.2014.01.001

Deli, M. (2007). Isolasi senyawa antioksidan dari tumbuhan obat Ekor Naga.

Dillasamola, D., Dharma, S., Aldi, Y., Berd, I., Hadyan, A., \& Biomechy Oktomalio, P. (2016). Antiinflammatory effects test of ethanol extract of mistletoe leaves coffee Scurrula ferruginea (jack) danser with methods granuloma pouch. Der Pharma Chemica.

Fahrimal, Y., Eliawardani, Rafina, A., Azhar, A., \& Asmilia, N. (2014). Blood Profile of Rats (Rattus norvegicus) Infected with Trypanosoma evansi Treated with Willow Tree Bark Extract (Salix tetrasperma Roxb). Jurnal Kedokteran Hewan. https://doi.org/10.2466/pms.104.3.799-802

Hamghalam, M., \& Ayatollahi, A. (2009). Automatic counting of leukocytes in Giemsa-stained images of peripheral blood smear. Proceedings - 2009 International Conference on Digital Image Processing, ICDIP 2009, 13-16. https://doi.org/10.1109/ICDIP.2009.9

Koh, T. J., \& DiPietro, L. A. (2011). Inflammation and wound healing: the role of the macrophage. Expert Reviews in Molecular Medicine, 13(July 2011). https://doi.org/10.1017/S1462399411001943

Kumar, V., Abbas, A. K., \& Aster, J. C. (2018). Robbins Basic Pathology, Tenth Edition. In Elsevier Inc.

Lee, Y. Y., Park, J. S., Lee, E. J., Lee, S. Y., Kim, D. H., Kang, J. L., \& Kim, H. S. (2015). Antiinflammatory Mechanism of Ginseng Saponin Metabolite Rh3 in Lipopolysaccharide-Stimulated Microglia: Critical Role of 5'-Adenosine Monophosphate-Activated Protein Kinase Signaling Pathway. Journal of Agricultural and Food Chemistry. https://doi.org/10.1021/jf506110y

Masfria, Hap, U. H., Nasution, M. P., \& Ilyas, S. (2014). Cytotoxic activity, proliferation inhibition, and apoptosis induction of rhaphidophora pinnata (L.F.) Schott chloroform fraction to MCF-7 cell line. International Journal of PharmTech Research.

Necas, J., \& Bartosikova, L. (2013). Carrageenan: A review. Veterinarni Medicina, 58(4), 187-205. https://doi.org/10.17221/6758-VETMED

Nuralifah, N., Jabbar, A., Parawansah, P., \& Iko, R. A. (2018). Uji Toksisitas Akut Ekstrak Etanol Daun Notika (Archboldiodendron calosercium (Kobuski)) Terhadap Larva Artemia salina Leach dengan menggunakan metode Brine Shrimp Lethality Test (BSLT). Pharmauho: Jurnal Farmasi, Sains, Dan Kesehatan, 4(1), 1-5. https://doi.org/10.33772/pharmauho.v4i1.4618

Pastar, I., Stojadinovic, O., Yin, N. C., Ramirez, H., Nusbaum, A. G., Sawaya, A., Patel, S. B., Khalid, L., Isseroff, R. R., \& Tomic-Canic, M. (2014). Epithelialization in Wound Healing: A Comprehensive Review. Advances in Wound Care, 3(7), 445-464. https://doi.org/10.1089/wound.2013.0473

Phillipson, M., \& Kubes, P. (2019). The Healing Power of Neutrophils. Trends in Immunology, 40(7), 635-647. https://doi.org/10.1016/j.it.2019.05.001

Prame Kumar, K., Nicholls, A. J., \& Wong, C. H. Y. (2018). Partners in crime: neutrophils and monocytes/macrophages in inflammation and disease. Cell and Tissue Research, 371(3), 551565. https://doi.org/10.1007/s00441-017-2753-2

Rahman, S. and A. M. K. (2019). Uji efek epitelisasi ekstrak daun ekor naga ( Rhaphidophora pinnata). Asy-syifaa jurnal. 11(01), 75-81. https://doi.org/10.33096/jifa.v11i1.516

Schmidt, S., Moser, M., \& Sperandio, M. (2013). The molecular basis of leukocyte recruitment and its deficiencies. $\quad$ Molecular Immunology, $\quad 55(1), \quad 58$ 4 https://doi.org/10.1016/j.molimm.2012.11.006

Singh, A., Malhotra, S., \& Subban, R. (2008). Anti-inflammatory and analgesic agents from Indian medicinal plants. International Journal of Integrative Biology, 3(1), 57-72.

Stankov, S. (2012). Definition of Inflammation, Causes of Inflammation, and Possible Antiinflammatory Strategies. The Open Inflammation Journal, 5(1), 1-9. 
https://doi.org/10.2174/1875041901205010001

Sukmawati, S., Yuliet, Y., \& Hardani, R. (2015). Uji aktivitas antiinflamasi ekstrak etanol daun pisang ambon (Musa paradisiaca L.) terhadap tikus putih (Rattus norvegicus L.) yang diinduksi karagenan. Jurnal Farmasi Galenika (Galenika Journal of Pharmacy) (e-Journal). https://doi.org/10.22487/j24428744.2015.v1.i2.6244

Sumaiyah, Masfria, \& Dalimunthe, A. (2018). Determination of total phenolic content, total flavonoid content, and antimutagenic activity of ethanol extract nanoparticles of rhaphidophora pinnata (L.f) Schott leaves. Rasayan Journal of Chemistry. https://doi.org/10.5220/0008360402240226

Syukri, Y., Purwati, R., Hazami, N., Anshory Tahmid, H., \& Fitria, A. (2020). Standardization of Specific and Non-Specific Parameters of Propolis Extract as Raw Material for Herbal Product. EKSAKTA: Journal of Sciences and Data Analysis, 1(1), 36-43. https://doi.org/10.20885/eksakta.vol1.iss1.art6

Thome, S., Begandt, D., Pick, R., Salvermoser, M., \& Walzog, B. (2018). Intracellular $\beta 2$ integrin (CD11/CD18) interacting partners in neutrophil trafficking. European Journal of Clinical Investigation, 48, 1-12. https://doi.org/10.1111/eci.12966

Verawati, V., Arel, A., \& Monika, M. (2015). Uji Efek Antiinflamasi Fraksi Daun Piladang (Solenostemonscutellarioides (L.) Codd) terhadap Mencit Putih Betina. Scientia : Jurnal Farmasi Dan Kesehatan. https://doi.org/10.36434/scientia.v5i2.27 